\title{
Evaluation of Antibacterial, Antifungal and Phytochemical Screening of Solanum nigrum
}

Khalid Bashir Dar ${ }^{1}$, Aashiq Hussain Bhat ${ }^{1}$, Shajrul Amin², Mohammad Afzal Zargar ${ }^{1}$, Akbar Masood², Akhtar Hussain Malik ${ }^{3}$ and Showkat Ahmad Ganie ${ }^{1 *}$

${ }^{1}$ Department of Clinical Biochemistry, University of Kashmir, India

${ }^{2}$ Department of Biochemistry, University of Kashmir, India

${ }^{3}$ Department of Botany, Centre for Biodiversity and Taxonomy, University of Kashmir, India

\begin{abstract}
The present study aimed at evaluating the antimicrobial potential of aqueous and methanolic extracts of Solanum nigrum, a traditionally used medicinal plant with multiple therapeutic properties. The susceptibility of microbial strains to the two extracts was determined using agar well diffusion method. The bacterial strains employed were Bacillus subtilis, Staphylococcus aureus, Klebsiella pneumoniae, Pseudomonas aeruginosa, Proteus vulgaris and Escherichia coli. The fungal strains used were Penicillium Chrysogenum, Aspergillus fumigatus, Candida albicans and Saccharomyces cerevisiae. Phytochemical screening was performed using standard methods. A dose dependent increase in the antibacterial activity was observed with both the methanol and aqueous extracts. Highest antibacterial activity was exhibited by aqueous extract with Escherichia coli $(16 \pm 0.23 \mathrm{~mm})$ followed by Staphylococcus aureus $(15 \pm 0.15$ $\mathrm{mm}$ ) at the concentration of $100 \mathrm{mg} / \mathrm{ml}$ plant extract. Methanolic extract showed highest antibacterial activity against Staphylococcus aureus and Pseudomonas aeruginosa with zone of inhibition $(14 \pm 0.11 \mathrm{~mm})$ and $(14 \pm 0.26 \mathrm{~mm})$ at the same concentration $(100 \mathrm{mg} / \mathrm{ml})$ respectively. The highest antifungal potential was exhibited by the methanolic extract against Saccharomyces cerevisiae $(26 \pm 0.27 \mathrm{~mm})$ and Candida albicans $(22 \pm 0.13 \mathrm{~mm})$, while the aqueous extract exhibits the highest antifungal potential against Saccharomyces cerevisiae $(23 \pm 0.14 \mathrm{~mm})$ followed by Candida albicans $(21 \pm 0.10 \mathrm{~mm})$ and Aspergillus fumigatus $(16 \pm 0.11 \mathrm{~mm})$ at the concentration of $100 \mathrm{mg} / \mathrm{ml}$. Phytochemical analysis revealed the plant is rich in various secondary metabolites like alkaloids, saponins, flavonoids, phenols and volatile oils. Cardenolides and phlobtannins were found absent. The study concludes that the plant possess novel compounds with significant antibacterial and antifungal properties. Isolation and characterization of these novel compounds could provide potent antimicrobial agents to combat pathogenic infections.
\end{abstract}

Keywords: Solanum nigrum; Microbial strains; Phytochemicals; Extracts; Anti-microbial

\section{Introduction}

Pathogenic microbes always posed serious threats to the health of humans and other animals. Microbes such as bacteria, viruses, fungi or protozoans are the causative agents of numerous infectious diseases like tuberculosis, AIDS, syphilis, candidiasis, aspergillosis, amoebiasis, poliomyelitis, etc. In fact infective diseases are the second leading cause of death worldwide [1]. Human beings are being infected by infectious microbes from times immemorable till now. Microbes like Psudomonas aeruginosa, Klebsiella pneumonia, and Escherichia coli cause skin infections, septicemia, upper and lower respiratory infections. E. coli is also involved in causing gynecological infections. Staphylococcus aureus causes intra-abdominal infections, bone and joint infections, lower respiratory infections as well as skin infections. Proteus vulgaris is an opportunistic pathogen responsible for causing urinary tract infections (UTI) and wound infections [2]. Bacillus subtilis acts as an opportunistic pathogen, producing harmful toxins that can sometimes lead to food poisoning [3]. Candida albicans is the causative agent of candidiasis. Aspergillus fumigatus causes allergic broncho-pulmonary aspergillosis and chronic pulmonary infections [4] Penicillium chrysogenum causes infection in people with severely suppressed immune systems like those with human immunodeficiency virus (HIV) and is characterized by pulmonary infection such as pneumoniae, localized granulomas and systemic infection. The airborne asexual spores of Penicillium chrysogenum act as allergens for human beings, inducing allergic reactions [5]. While as $1 \%$ of all vaginal yeast infections occur due to Saccharomyces cerevisiae [6].

Medicinal plants were the first weapons used by man to treat pathogenic infections. With the discovery of antibiotics in the beginning of $20^{\text {th }}$ century, scientists begin to develop synthetic antimicrobials, derived from microbial sources. Ironically, excessive use of these synthetic drugs in human beings and other animals, besides their growing presence in soil, water and food contributed to the serious problem of antimicrobial resistance (AMR) [7]. Today, AMR is a major health concern that has rendered many antibiotics ineffective. After more than 50 years of widespread use of so called "miracle drugs", synthetic antibiotics are no longer as effective as they once used to be. There is an alarming increase in the number of multiple drug resistant (MDR) strains. In fact, most of the bacterial infections throughout the world are becoming resistant to antibiotics $[8,9]$. There is also a drastic decline in the production of new synthetic antibiotics [10]. Further, synthetic antibiotics are associated with adverse effects on host by causing hypersensitivity, immune suppression and allergic reactions [11]. Therefore there is desperate need to develop alternate antimicrobial drugs for the treatment of various infectious diseases from medicinal plant sources [12].

The plant kingdom is a treasure house of potential therapeutic

*Corresponding author: Showkat Ahmad Ganie, Department of Clinical Biochemistry, University of Kashmir, India, Tel: 9194199726780; E-mail: Showkat_ganie786@yahoo.com; showkatganie@kashmiruniversity.ac.in

Received: July 03, 2016; Accepted: February 07, 2017; Published February 10 2017

Citation: Dar KB, Bhat AH, Amin S, Zargar MA, Masood A, et al. (2017) Evaluation of Antibacterial, Antifungal and Phytochemical Screening of Solanum nigrum. Biochem Anal Biochem 6: 309. doi: 10.4172/2161-1009.1000309

Copyright: $\odot 2017$ Dar KB, et al. This is an open-access article distributed unde the terms of the Creative Commons Attribution License, which permits unrestricted use, distribution, and reproduction in any medium, provided the original author and source are credited. 
drugs. It is estimated that there are about 2.5 lakh to 5.0 lakh species of plants on earth [13]. Among them only a negligible percentage has been explored for phytochemicals and medicinal properties. In fact only less than $1 \%$ of some 250,000 higher plants have been screened for their phytochemistry or pharmacology [14]. Medicinal plants are rich sources of antimicrobial phytochemicals notably flavonoids, saponins, tannins, alkaloids, phenols, terpenes and terpenoids $[15,16]$. Scientific studies have proven the antimicrobial potential of herbal extracts against different pathogenic microbes $[17,18]$. It is worth to mention that antimicrobial Phytoconstituents are the emerging alternatives for the control of pathogenic microorganisms.

The present study was conducted to evaluate the antimicrobial potential of the plant against some bacterial and fungal strains. Solanum nigrum, commonly known as black nightshade is a member of the Solanaceae family. Locally, it is known as "Kambai". It is a short lived perennial shrub that usually grows in moist habitats. Solanum nigrum is a traditionally used important medicinal plant with multiple therapeutic properties such as antiproliferative, antiseizure, antiinflammatory, antipoison, antioxidant and antipyretic activity [19]. Some traditional uses of the plant include the treatment of pain, inflammation and fever [20,21]. In India, its roots are boiled with a little sugar to increase fertility in women. Root juice is also used to treat asthma and whooping cough. Leaf paste is used to treat rabies and for wound healing. In Algeria, whole plant decoction is traditionally used to treat burns and dermal infections [19].

\section{Materials and Methods}

\section{Collection and identification of plant material}

Fresh whole plant samples of Solanum nigrum were collected from higher reaches of Kashmir Valley, India in the month of September (2014). The plant was identified by the courtesy of Centre of Plant Taxonomy (COPT), Department of Botany University of Kashmir and authenticated by Mr. Akhtar Hussain Malik (Curator). The specimen/ plant sample was properly labeled, numbered, noted with the date of collection and is well preserved in the herbarium of COPT, University of Kashmir under a specific voucher specimen number 2055-KASH.

\section{Preparation of extracts}

Whole plant sample was allowed to shade dry at $30 \pm 2^{\circ} \mathrm{C}$. The dried plant material was ground into coarse powder with the help of grinder and extracted using methanol and water as solvents, by using Soxhlet extractor $\left(60^{\circ} \mathrm{C}\right.$ to $\left.80^{\circ} \mathrm{C}\right)$. The solvent extracts so obtained were concentrated with the help of rotary evaporator under reduced pressure to obtain solid extracts. Five different concentrations i.e., $10,30,50,80$ and 100 milligram/millilitre $(\mathrm{mg} / \mathrm{ml})$ of both aqueous and methanolic extracts were prepared by dissolving solid extracts in $10 \%$ dimethylsulfoxide (DMSO). Extracts so prepared were stored in a refrigerator at $4^{\circ} \mathrm{C}$ for further use.

\section{Test micro-organisms}

Six bacterial strains including two Gram positive bacteria namely Staphylococcus aureus (MTCC-2940), Bacillus subtilis (MTCC-441) and four Gram negative bacteria namely Proteus vulgaris (MTCC426), Klebsiella pneumoniae (MTCC-139), Escherichia coli (MTCC739), and Pseudomonas aeruginosa (MTCC-424) were employed for antibacterial assay. Four fungal strains, Candida albicans (MTCC-227), Saccharomyces cerevisiae (MTCC-170), Aspergillus fumigatus (MTCC1811) and Penicillium chrysogenum (MTCC-947) were employed for antifungal assay. The Bacterial and fungal strains were obtained from
Microbial Type Culture Collection, Institute of Microbial Technology (IMTECH), Chandigarh, India. Bacterial and fungal strains were maintained by sub-culturing them on Mueller Hinton Agar (Himedia) and Sabouraud Dextrose Agar (Himedia) respectively after every fifteen days and then stored at $4^{\circ} \mathrm{C}$.

Gentamycin discs and Nystatin powder was obtained from EOS Laboratories, India and served as positive controls for antibacterial and antifungal assays respectively. $10 \%$ Dimethylsulfoxide (Himedia) was used as negative control.

\section{Antibacterial assay}

Antibacterial assay for aqueous and methanolic ectracts was performed by agar well diffusion method as described by Irshad et al. [22] with some modification. $100 \mu \mathrm{l}$ of standardized inoculum $(0.5$ Mc Farland) of each test bacterium was inoculated on molten Mueller Hinton Agar (Himedia), homogenised and then poured into sterile petri plates to yield a uniform depth of $4 \mathrm{~mm}$. The petriplates were allowed to solidify inside the laminar hood. Sterile cork borers of 5 $\mathrm{mm}$ in diameter were used to make uniform and equidistant wells into each petriplate. $100 \mu \mathrm{l}$ of each concentration $(10 \mathrm{mg} / \mathrm{ml}, 30 \mathrm{mg} / \mathrm{ml}, 50$ $\mathrm{mg} / \mathrm{ml}, 80 \mathrm{mg} / \mathrm{ml}$ and $100 \mathrm{mg} / \mathrm{ml}$ ) of plant extracts, prepared in $10 \%$ dimethylsulfoxide (DMSO) were loaded into different peripheral wells. Gentamycin $(10 \mu \mathrm{g} / \mathrm{disc})$ disc was placed at the centre of each petriplate and served as positive control, while as $10 \%$ dimethylsulfoxide served as negative control in a separate petri plate. The petri plates were then incubated at $37^{\circ} \mathrm{C}$ for 18 to 24 hours in an incubator. The plates were then observed for the zones of inhibition. Antibacterial potential was evaluated by measuring the diameters of zones of inhibition in millimeters $(\mathrm{mm})$ with the help of a standard measuring scale.

\section{Antifungal assay}

Antifungal assay for aqueous and methanolic extracts was performed by agar well diffusion method as described by Ahmad et al. [23] with some modification. $100 \mu$ l of standardized inoculum ( $0.5 \mathrm{Mc}$ Farland) of each test fungi were inoculated on sterile molten Sabouraud Dextrose Agar (Himedia), homogenised and poured into a sterile petri plate to yield a uniform depth of $4 \mathrm{~mm}$. The petriplates were allowed to solidify inside the laminar hood. Sterile cork borers of $5 \mathrm{~mm}$ in diameter were used to make five wells at periphery and one well at centre of each petriplate. $100 \mu \mathrm{l}$ of each concentration $(10 \mathrm{mg} / \mathrm{ml}, 30$ $\mathrm{mg} / \mathrm{ml}, 50 \mathrm{mg} / \mathrm{ml}, 80 \mathrm{mg} / \mathrm{ml}$ and $100 \mathrm{mg} / \mathrm{ml}$ ) of plant extract, prepared in $10 \%$ dimethylsulfoxide (DMSO) were loaded into five different peripheral wells. $100 \mu \mathrm{l}$ of standard antibiotic Nystatin $(0.5 \mathrm{mg} / \mathrm{ml})$ was loaded into the central well while as $10 \%$ dimethylsulfoxide alone was used as negative control in a separate petri plate. The plates were then incubated at $32^{\circ} \mathrm{C}$ for 24 to 36 hours. After incubation period, the plates were observed for the zones of inhibition. Antifungal potential was evaluated by measuring inhibition zone diameters in millimeters $(\mathrm{mm})$ with the help of standard measuring scale.

\section{Phytochemical analysis}

Preliminary phytochemical screening of aqueous and methanolic extracts of Solanum nigrum was done according to methods described by Harborne [24].

\section{Statistical analysis}

The values of zones of inhibition were expressed as mean \pm standard deviation (SD) of three independent experiments. The results were evaluated by using SPSS (version 12.0) and evaluated by one way ANOVA followed by Bonferroni t-test. Statistical significance was considered when value of $P<0.05$. 
Citation: Dar KB, Bhat AH, Amin S, Zargar MA, Masood A, et al. (2017) Evaluation of Antibacterial, Antifungal and Phytochemical Screening of Solanum nigrum. Biochem Anal Biochem 6: 309. doi: 10.4172/2161-1009.1000309

\section{Results}

\section{Anti-bacterial activity}

The antibacterial activity of the plant varied with the type of bacterial strain and the extract used. Out of the two extracts used, the aqueous extract was found more potent against Escherichia coli (16 \pm

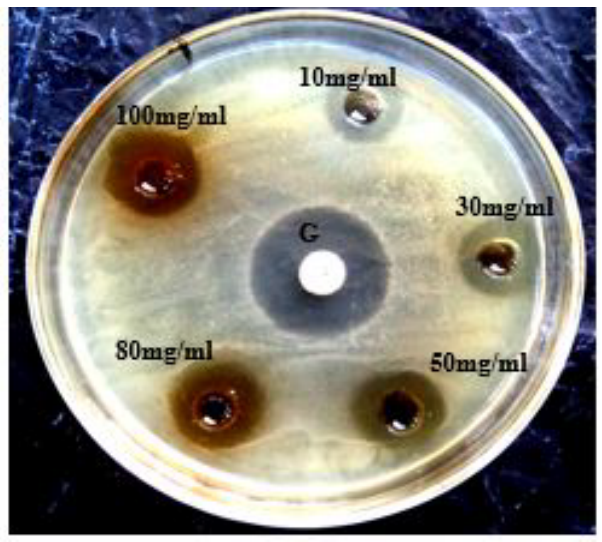

Figure 1: Shows concentration dependent increase in the antibacterial potential of aqueous extract of Solanum nigrum $(10-100 \mathrm{mg} / \mathrm{ml})$ against $E$. coli in comparison to positive control Gentamycin (G).

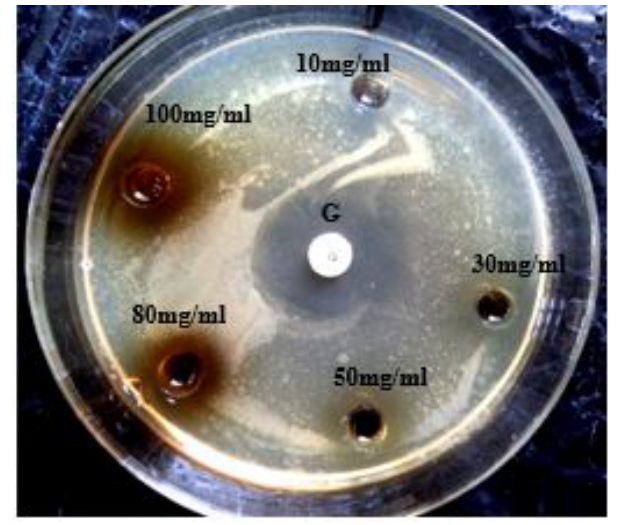

Figure 2: Shows concentration dependent increase in the antibacterial potential of aqueous extract of Solanum nigrum $(10-100 \mathrm{mg} / \mathrm{ml})$ against S.aureus in comparison to positive control Gentamycin (G).

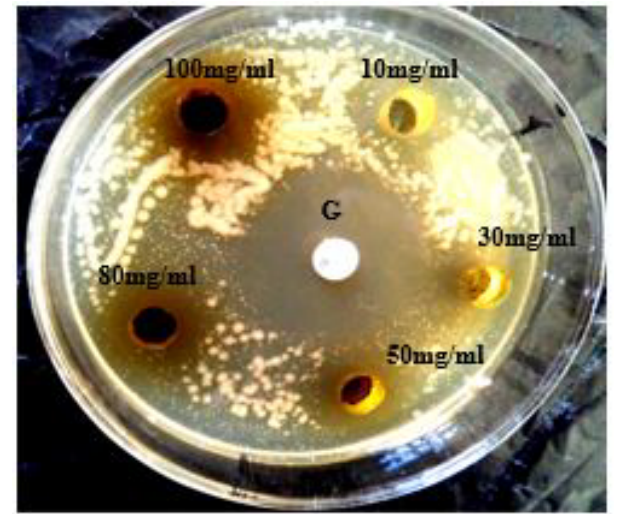

Figure 3: Shows concentration dependent increase in the antibacterial potential of methanol extract of Solanum nigrum $(10-100 \mathrm{mg} / \mathrm{ml})$ against $P$. aeruginosa in comparison to positive control Gentamycin (G).

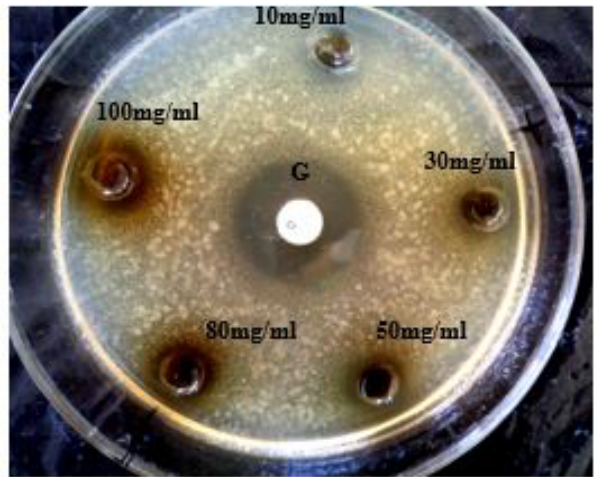

Figure 4: Shows concentration dependent increase in the antibacterial potential of methanol extract of Solanum nigrum $(10-100 \mathrm{mg} / \mathrm{ml})$ against $S$.aureus in comparison to positive control Gentamycin (G).

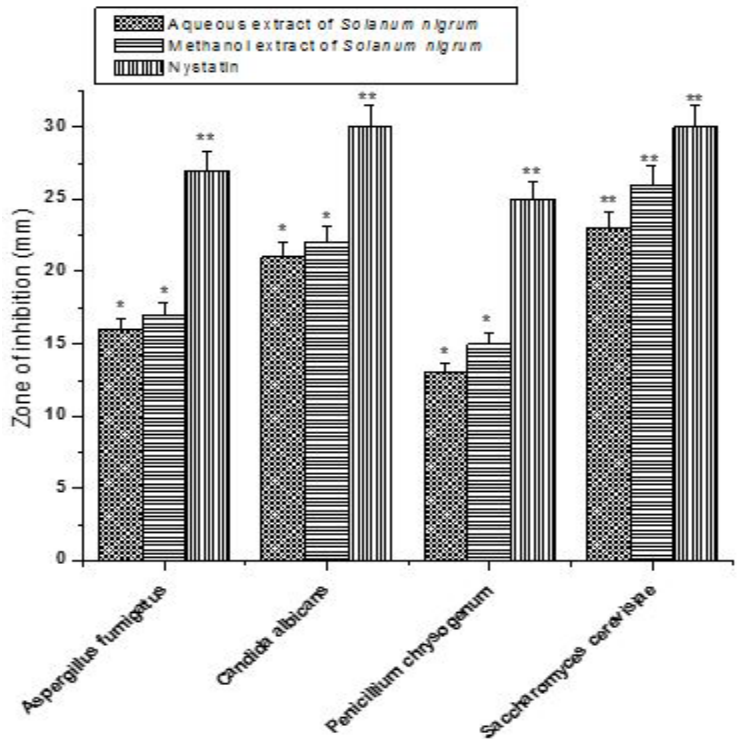

Figure 5: Zones of inhibition in millimeters at the highest concentration of $100 \mathrm{mg} / \mathrm{ml}$ of aqueous and methanolic extract of Solanum nigrum against different bacterial strains. The results represent mean \pm S.D of 3 independent experiments and evaluated by one-way ANOVA followed by the Bonferroni t-test. Differences were considered to be statistically significant if $\mathrm{P}<0.05$.

$0.23 \mathrm{~mm}$ ) (Figure 1) and Staphylococcus aureus $(15 \pm 0.15 \mathrm{~mm}$ ) (Figure 2) at the concentration of $100 \mathrm{mg} / \mathrm{ml}$ respectively, while the methanolic extract was found most effective against Pseudomonas aeruginosa (14 $\pm 0.26 \mathrm{~mm}$ ) (Figure 3) and Staphylococcus aureus $(14 \pm 0.11 \mathrm{~mm}$ ) (Figure 4). The results were compared to a standard antibacterial drug, Gentamycin $(G)$ which showed the zone of inhibition of $25 \pm$ $1.32 \mathrm{~mm}$ against Klebsiella pneumoniae and Bacillus subtilis, $25 \pm$ $1.02 \mathrm{~mm}$ against Proteus vulgaris, $25 \pm 1.36 \mathrm{~mm}$ against Pseudomonas aeruginosa, $20 \pm 1.92 \mathrm{~mm}$ against Escherichia coli and $27 \pm 1.25 \mathrm{~mm}$ against Staphylococcus aureus respectively (Figure 5). 10\% DMSO (negative control) showed no activity against any of the tested bacterial strains. The detailed results of the antibacterial potential of plant extracts are shown in Table 1.

\section{Anti-fungal activity}

Methanolic extract showed maximum activity against all the tested fungal strains with the zones of inhibition equal to $17 \pm 0.20 \mathrm{~mm}$ (Aspergillus fumigates), $22 \pm 0.13 \mathrm{~mm}$ (Candida albicans) (Figure 6), 15 
Citation: Dar KB, Bhat AH, Amin S, Zargar MA, Masood A, et al. (2017) Evaluation of Antibacterial, Antifungal and Phytochemical Screening of Solanum nigrum. Biochem Anal Biochem 6: 309. doi: 10.4172/2161-1009.1000309

Page 4 of 6

\begin{tabular}{|c|c|c|c|c|c|c|c|}
\hline \multirow[b]{2}{*}{ Bacterial strain } & \multirow[b]{2}{*}{ Solvent } & \multicolumn{5}{|c|}{ Concentration of plant extract } & \multirow[b]{2}{*}{ Gentamycin $(10 \mu \mathrm{g} / \mathrm{disc})$} \\
\hline & & $10 \mathrm{mg} / \mathrm{ml}$ & $30 \mathrm{mg} / \mathrm{ml}$ & $50 \mathrm{mg} / \mathrm{ml}$ & $80 \mathrm{mg} / \mathrm{ml}$ & $100 \mathrm{mg} / \mathrm{ml}$ & \\
\hline \multirow{2}{*}{ Klebsiella pneumoniae } & Aqueous & - & - & - & $11 \pm 0.13^{*}$ & $12 \pm 0.15^{*}$ & \multirow{2}{*}{$25 \pm 1.32$} \\
\hline & Methanol & - & $8 \pm 0.23^{*}$ & $9 \pm 0.56^{*}$ & $10 \pm 0.34^{*}$ & $10 \pm 0.33^{*}$ & \\
\hline \multirow{2}{*}{ Escherichia coli } & Aqueous & $12 \pm 0.26^{*}$ & $13 \pm 0.30^{*}$ & $14 \pm 0.33^{*}$ & $15 \pm 0.21^{*}$ & $16 \pm 0.23^{*}$ & \multirow{2}{*}{$20 \pm 1.92$} \\
\hline & Methanol & $9 \pm 0.12^{*}$ & $10 \pm 0.17^{*}$ & $11 \pm 0.24^{\star}$ & $12 \pm 0.14^{\star}$ & $13 \pm 0.16^{*}$ & \\
\hline \multirow{2}{*}{ Proteus vulgaris } & Aqueous & $9 \pm 0.15^{*}$ & $10 \pm 0.36^{*}$ & $10 \pm 0.20^{*}$ & $11 \pm 0.22^{*}$ & $12 \pm 0.29^{*}$ & \multirow{2}{*}{$25 \pm 1.02$} \\
\hline & Methanol & - & - & - & - & $10 \pm 0.13^{*}$ & \\
\hline \multirow{2}{*}{ Staphylococcus aureus } & Aqueous & $11 \pm 0.10^{*}$ & $12 \pm 0.21^{*}$ & $13 \pm 0.27^{*}$ & $13 \pm 0.33^{\star}$ & $15 \pm 0.15^{*}$ & \multirow[t]{2}{*}{$27 \pm 1.25$} \\
\hline & Methanol & - & $11 \pm 0.13^{*}$ & $12 \pm 0.11^{\star}$ & $13 \pm 0.14^{*}$ & $14 \pm 0.11^{\star}$ & \\
\hline \multirow{2}{*}{ Pseudomonas aeruginosa } & Aqueous & $9 \pm 0.15^{*}$ & $10 \pm 0.36^{*}$ & $10 \pm 0.27^{\star}$ & $10 \pm 0.19^{*}$ & $11 \pm 0.20^{*}$ & \multirow[t]{2}{*}{$25 \pm 1.36$} \\
\hline & Methanol & $10 \pm 0.11^{*}$ & $11 \pm 0.28^{*}$ & $12 \pm 0.25^{*}$ & $13 \pm 0.31^{*}$ & $14 \pm 0.26^{*}$ & \\
\hline \multirow{2}{*}{ Bacillus subtilis } & Aqueous & $9 \pm 0.12^{*}$ & $10 \pm 0.32^{*}$ & $11 \pm 0.34^{*}$ & $12 \pm .013^{*}$ & $13 \pm 0.19^{*}$ & \multirow{2}{*}{$25 \pm 1.32$} \\
\hline & Methanol & - & - & - & - & - & \\
\hline
\end{tabular}

Minus sign (-) indicates no activity

Each value represents the mean \pm SD of three independent experiments and evaluated by one way ANOVA followed by the Bonferroni t-test. Differences were considered to be statistically significant if $\mathrm{P}<0.05$.

Table 1: Showing zones of inhibition (in millimeter) of aqueous and methanolic extract of Solanum nigrum against bacterial strains

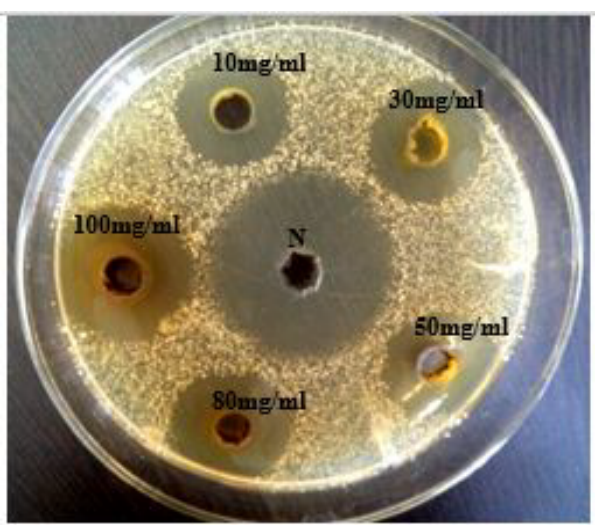

Figure 6: Shows concentration dependent increase in the antifungal potential of methanol extract of Solanum nigrum $(10-100 \mathrm{mg} / \mathrm{ml})$ against $C$. albicans in comparison to positive control Nystatin $(\mathrm{N})$

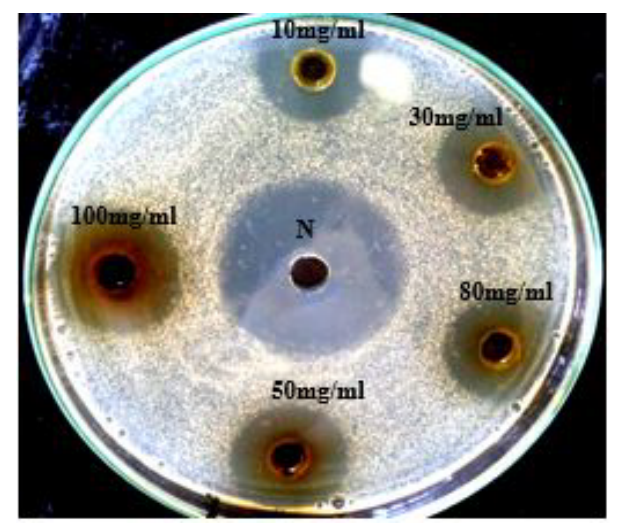

Figure 7: Shows concentration dependent increase in the antifungal potentia of methanol extract of Solanum nigrum $(10-100 \mathrm{mg} / \mathrm{ml})$ against $S$. cerevisiae in comparison to positive control Nystatin (N).

$\pm 0.22 \mathrm{~mm}$ (Penicillium chrysogenum) and $26 \pm 0.27 \mathrm{~mm}$ (Saccharomyces cerevisiae) (Figure 7) respectively at the concentration of $100 \mathrm{mg} / \mathrm{ml}$. Aqueous extract was observed more potent against Saccharomyces cerevisiae with zone of inhibition $23 \pm 0.14 \mathrm{~mm}$ (Figure 8) and Candida albicans with zone of inhibition $21 \pm 0.10 \mathrm{~mm}$ (Figure 9). The results were compared to that of standard antifungal drug, Nystatin $(\mathrm{N})$ which exhibited the zone of inhibition equal to $30 \pm 1.59 \mathrm{~mm}$ against Candida albicans, $30 \pm 1.81 \mathrm{~mm}$ against Saccharomyces cerevisiae, $27 \pm 1.11 \mathrm{~mm}$ against Aspergillus fumigatus and $25 \pm 1.06 \mathrm{~mm}$ against Penicillium chrysogenum (Figure 10). 10\% DMSO (negative control) showed no activity against any of the tested fungal strains. The detailed antifungal potential of plant extracts is provided in Table 2.

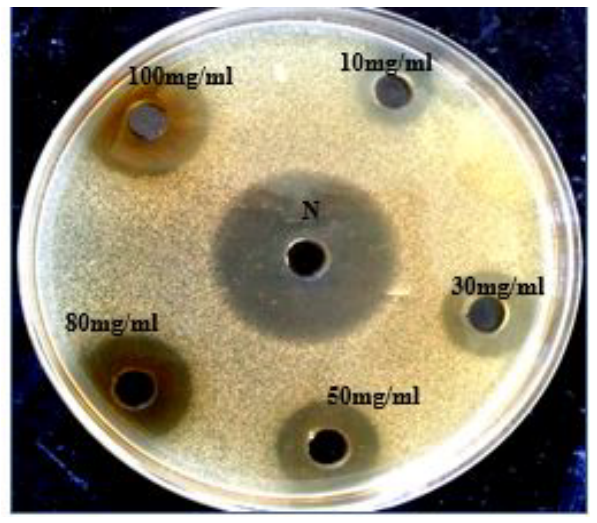

Figure 8: Shows concentration dependent increase in the antifungal potentia of aqueous extract of Solanum nigrum $(10-100 \mathrm{mg} / \mathrm{ml})$ against $\mathrm{S}$. cerevisiae in comparison to positive control Nystatin (N).

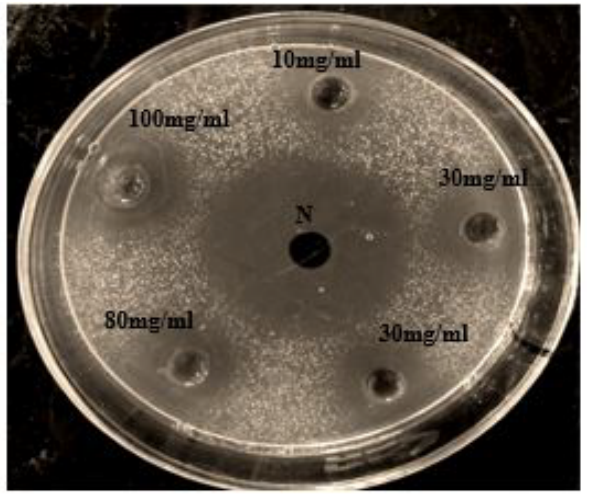

Figure 9: Shows concentration dependent increase in the antifungal potentia of aqueous extract of Solanum nigrum $(10-100 \mathrm{mg} / \mathrm{ml})$ against C. albicans in comparison to positive control Nystatin $(\mathrm{N})$. 
Citation: Dar KB, Bhat AH, Amin S, Zargar MA, Masood A, et al. (2017) Evaluation of Antibacterial, Antifungal and Phytochemical Screening of Solanum nigrum. Biochem Anal Biochem 6: 309. doi: 10.4172/2161-1009.1000309

Page 5 of 6

\section{Phytochemical analysis}

Phytochemicals are non-nutritive substances of plants that have disease preventive properties. The phytochemical analysis of

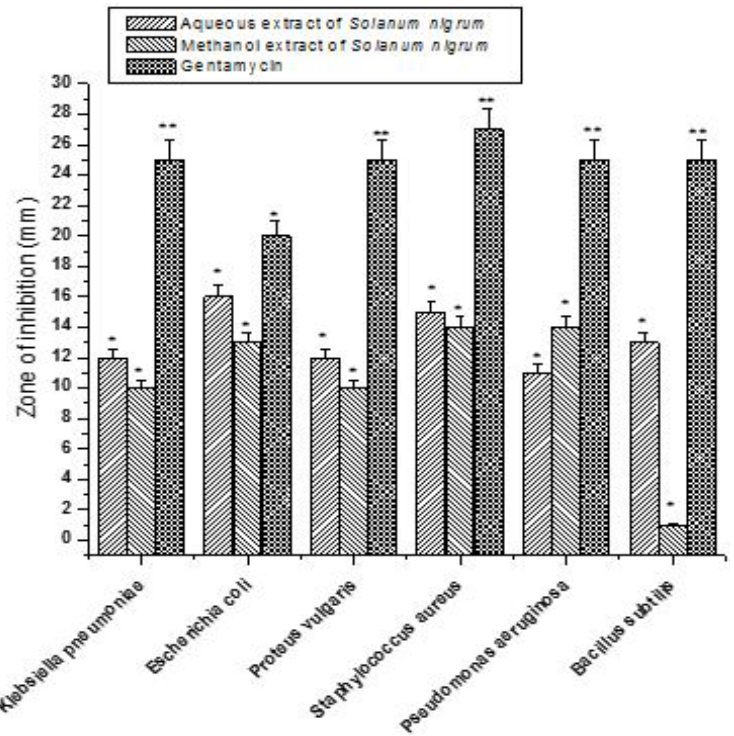

Figure 10: Zones of inhibition in millimeters at the highest concentration of 100 $\mathrm{mg} / \mathrm{ml}$ of aqueous and methanolic extract of Solanum nigrum against different fungal strains. The results represent mean \pm S.D of 3 independent experiments and evaluated by one-way ANOVA followed by the Bonferroni t-test. Differences were considered to be statistically significant if $\mathrm{P}<0.05$
Solanum nigrum revealed the presence of alkaloids, cardiac glycosides, flavonoids, saponins, tannins and volatile oils in both aqueous and methanolic extracts. Anthraquinones and phenols were detected only in aqueous extracts while as the steroids and terpenoids were present only in methanolic extract. Cardenolides and phlobtannins were absent in both the extracts as shown in Table 3.

\section{Discussion}

In the present study, the aqueous extract of Solanum nigrum was found effective against most of the bacterial strains while the methanolic extract was found effective against fungal strains. This could be due to the presence of different phytochemicals in different solvents as a result of differences in their relative polarities/solubilities as reported by many studies [25-27]. Traditional healers used only water for the purpose of extraction but studies have proven the importance of the type of extracting solvent in determining the pharmacological activity of a medicinal plant [28]. As far as susceptibility of microbes is concerned, Escherichia coli and Staphylococcus aureus were found most susceptible bacterial strain, while as Saccharomyces cerevisiae and Candida albicans were the most susceptible fungal strains. Similar results were reported by Antara and Amla, while studying the antimicrobial activity of different solvent extracts of Melia azedarach L [29]. Phytochemical studies indicate that the plant is rich in compounds like alkaloids, flavonoids, saponins tannins, phenols, cardiac glycosides and volatile oils. Our results are in good agreement with those reported by Belkacem et al. while performing the phytochemical screening of various extracts of Punica granatum L [30]. The plant may possess antimicrobial activity due to the presence of any of these phytoconstituents which

\begin{tabular}{|c|c|c|c|c|c|c|c|}
\hline \multirow[b]{2}{*}{ Fungal strain } & \multirow[b]{2}{*}{ Solvent } & \multicolumn{5}{|c|}{ Concentration of plant extract } & \multirow[b]{2}{*}{$\begin{array}{c}\text { Nystatin } \\
(0.5 \mathrm{mg} / \mathrm{ml})\end{array}$} \\
\hline & & $10 \mathrm{mg} / \mathrm{ml}$ & $30 \mathrm{mg} / \mathrm{ml}$ & $50 \mathrm{mg} / \mathrm{ml}$ & $80 \mathrm{mg} / \mathrm{ml}$ & $100 \mathrm{mg} / \mathrm{ml}$ & \\
\hline \multirow{2}{*}{ Aspergillus fumigatus } & Aqueous & $12 \pm 0.33^{*}$ & $13 \pm 0.22$ & $14 \pm 0.18^{\star}$ & $15 \pm 0.20^{*}$ & $16 \pm 0.11^{*}$ & \multirow{2}{*}{$27 \pm 1.11$} \\
\hline & Methanol & $12 \pm 0.29^{*}$ & $13 \pm 0.19^{*}$ & $14 \pm 0.23^{*}$ & $15 \pm 0.11^{*}$ & $17 \pm 0.20^{*}$ & \\
\hline \multirow{2}{*}{ Candida albicans } & Aqueous & $12 \pm 0.22^{*}$ & $15 \pm 0.15^{*}$ & $17 \pm 0.34^{*}$ & $19 \pm 0.33^{*}$ & $21 \pm 0.10^{\star}$ & \multirow{2}{*}{$30 \pm 1.59$} \\
\hline & Methanol & $17 \pm 0.24^{*}$ & $18 \pm 0.29^{*}$ & $19 \pm 0.17^{\star}$ & $20 \pm 0.30^{*}$ & $22 \pm 0.13^{* *}$ & \\
\hline \multirow{2}{*}{ Penicillium chrysogenum } & Aqueous & - & $10 \pm 0.11^{*}$ & $11 \pm 0.22^{*}$ & $12 \pm 0.31^{*}$ & $13 \pm 0.20^{*}$ & \multirow{2}{*}{$25 \pm 1.06$} \\
\hline & Methanol & $8 \pm 0.31^{\star}$ & $10 \pm 0.33^{*}$ & $12 \pm 0.36^{*}$ & $12 \pm 0.27^{*}$ & $15 \pm 0.22^{\star}$ & \\
\hline \multirow{2}{*}{ Saccharomyces cerevisiae } & Aqueous & $17 \pm 0.22^{*}$ & $18 \pm 0.10^{*}$ & $19 \pm 0.16^{\star}$ & $21 \pm 0.13^{* *}$ & $23 \pm 0.14^{* * *}$ & \multirow{2}{*}{$30 \pm 1.81$} \\
\hline & Methanol & $20 \pm 0.28^{*}$ & $21 \pm 0.23^{*}$ & $22 \pm 0.28^{\star}$ & $23 \pm 0.34^{* *}$ & $26 \pm 0.27^{+* t *}$ & \\
\hline
\end{tabular}

Minus sign (-) indicates no activity

Each value represents the mean \pm SD of three independent experiments and evaluated by one way ANOVA followed by the Bonferroni t-test. Differences were considered to be statistically significant if $\mathrm{P}<0.05$.

Table 2: Showing zones of inhibition (in millimeter) of aqueous and methanolic extract of Solanum nigrum against fungal strains

\begin{tabular}{|c|c|c|c|}
\hline \multirow[b]{2}{*}{ S. NO } & \multirow[b]{2}{*}{ Phytochemicals } & \multicolumn{2}{|c|}{ Solvents } \\
\hline & & Aqueous & Methanol \\
\hline 1 & Alkaloids & + & + \\
\hline 2 & Anthraquinones & + & - \\
\hline 3 & Cardiac glycosides & + & + \\
\hline 4 & Cardenolides & - & - \\
\hline 5 & Flavonoids & + & + \\
\hline 6 & Phenols & + & - \\
\hline 7 & Phlobtannins & - & - \\
\hline 8 & Saponins & + & + \\
\hline 9 & Steroids & - & + \\
\hline 10 & Tannins & + & + \\
\hline 11 & Terpenoids & - & + \\
\hline 12 & Volatile oils & + & + \\
\hline \multicolumn{4}{|c|}{$(+)=($ Present $),(-)=($ Absent $)$} \\
\hline
\end{tabular}

Table 3: Showing preliminary phytochemical screening of aqueous and methanolic extracts of Solanum nigrum. 
Citation: Dar KB, Bhat AH, Amin S, Zargar MA, Masood A, et al. (2017) Evaluation of Antibacterial, Antifungal and Phytochemical Screening of Solanum nigrum. Biochem Anal Biochem 6: 309. doi: 10.4172/2161-1009.1000309

may operate through varied mechanisms including the disruption of cell membrane, inhibition of cell wall formation, inactivation of microbial adhesins, suppression of enzymes or blocking of nucleic acid synthesis [31]. Further, the studies have proven that phytochemical compounds can even disrupt the activities of multiple drug resistant (MDR) microbes by influencing various parameters such as efflux pumps, beta-lactamase enzymes, resistance plasmids and bacterial gene transposition [32].

\section{Conclusion}

Present study has justified the claimed use of this plant in the traditional medicinal systems for the treatment of various infections. From the outcome of the study, it is concluded that the crude extracts of the plant possess considerable antimicrobial activity, especially against fungal strains used in the study. The plant may contain potent antimicrobial compounds, effective in the treatment of various fungal and bacterial infections. However, further investigation is needed in the direction of pure compound isolation, toxicological studies and clinical trials so as to use the promising compound(s) as effective antimicrobial agents.

\section{Acknowledgement}

The authors are greatly thankful to the Department of Clinical Biochemistry, University of Kashmir for providing all the necessary facilities to carry out this research work.

\section{References}

1. WHO (2002) Deaths by cause, sex and mortality stratum in WHO Regions estimates for 2001. World health report, World Health Organization, Geneva.

2. Karch A, Karch AM (2014) Lippincott Nursing Drug Guide, Lippincott Williams \& Wilkins, US.

3. Eley AR (1992) Toxic bacterial food poisoning. Microbial Food Poisoning 37-55

4. Segal BH (2009) Aspergillosis. Engl J Med 360:1870-1884.

5. Shen HD, Chou H, Tam MF, Chang CY, Lai HY, et al. (2003) Molecular and immunological characterization of Pen ch 18, the vacuolar serine protease major allergen of Penicillium chrysogenum. Allergy 58: 993-1002.

6. McCullough MJ, Clemons KV, Farina C, McCusker JH, Stevens DA (1998) Epidemiological investigation of vaginal Saccharomyces cerevisiae isolates by a genotypic method. J Clin Microbiol 36:557-562.

7. Moshirfar M, Mirzaian G, Feiz V, Kang PC (2006) Fourth-generation fluoroquinolone-resistant bacterial keratitis after refractive surgery. J Cataract Ref Sur 32:515-518.

8. Johnson JR, Clermont O, Menard M, Kuskowski MA, Picard B, et al. (2006) Experimental mouse lethality of Escherichia coli isolates in relation to accessory traits, phylogenetic groups, and clinical source. $\mathrm{J}$ infec diseases 194:1141-1150.

9. Woodford N, Ellington MJ (2007) The emergence of antibiotic resistance by mutation. Clin Microbiol Infec 13: 5-18.

10. Davis J (1994) Inactivation of the antibiotics and the dissemination of resistant genes. Science 264:375-382.

11. Ahmad I, Mehmood Z, Mohammad F (1996) Screening of some Indian medicinal plants for their antimicrobial properties. J Ethnopharmacol 62:183-193.
12. Cordell GA (2000) Biodiversity and drug discovery, a symbiotic relationship Phytochem 55: 463-480.

13. Borris RP (1996) Natural product research: Perspectives from a major pharmaceutical company. J Ethnopharmacol 51: 29-38.

14. Petlevski R, Hadzija M, Slijepcevic M, Juretie D (2001) Effect of anti-diabetes herbal preparation on serum glucose and fructosamine in NOD mice. $J$ Ethnopharmacol 75:181-184.

15. Tiwari S, Singh A (2004) Toxic and sub-lethal effects of oleadrin on biochemical parameters of freshwater air breathing murrel, Chant punctatus (Bloch.). Indian J Exper Biol 42:413-418.

16. Lewis K, Ausubel FM (2006) Prospects of plant derived anti-bacterials. Nat Biotechnol 24:1504-1507.

17. Sharvani KA, Jagadeesh $D$, Chandrakanth $R$, Sumana $K$, Seema $M$, et al. (2015) Antimicrobial assay of Elaeocarpus species of western ghats of karnataka. Asian J Pharmaceut Anal Med Chem 3:14-19.

18. Hussain KA, Tarakji B, Kandy BPP, John J, Mathews J, et al. (2015) antimicrobial effects of Citrus sinesis peel extracts against periodontopathic bacteria: An in vitro study. Rocz Panstw Zakl Hig 66:173-178.

19. Ramya J, Anjali S, Sanjay G, Indira S, Reema G (2011) Solanum nigrum: Current perspectives on therapeutic properties. Alter Med Rev 16:78-85.

20. Acharya E, Pokhrel B (2006) Ethno-medicinal plants used by Bantar of Bhaudaha, Morang, Nepal. Our Nat 4:96-103.

21. Zakaria ZA, Hanan-Kumar G, Zainal H, Mohd Pojan NH, Morsid NA, et al (2006) Antinociceptive, anti-inflammatory and antipyretic effects of Solanum nigrum chloroform extract in animal models. Yakugaku Zasshi 126: 1171-1178.

22. Irshad S, Mahmood M, Parveen F (2012) In vitro antibacterial activities of three medicinal plants using agar well diffusion method. Res J Biol 2: 1-8.

23. Ahmad N, Amir MK, Ayaz S, Ahmad, Jan A, et al. (2012) Antimicrobial profile of the selected medicinal plants. Int J Chem Lif Sci 01: 1039-1041.

24. Harborne JB (1998) Methods of extraction and isolation, In: Phytochemical Methods, Chapman and Hall, London 60-66.

25. Al-Zubaydi SR, Al-Hmdany MA, Raesan SJ (2009) Anti-bacterial effect of some medicinal plant extracts against some pathogenic bacteria strains. J Duhok Univ 12: 244-249.

26. Bakht J, Tayyab M, Ali H, Islam A, Shafi M (2011) Effect of different solvent extracted sample of Allium sativum (Linn) on bacteria and fungi. Afr J Biotechnol 10: 5910-5915.

27. Boklari FM (2009) Antifungal activity of some medicinal plants used in Jeddah, Saudi Arabia. Mycopathologia 7: 51-57.

28. Parekh J, Jadeja D, Chanda S (2005) Efficacy of aqueous and methanol extracts of some medicinal plants for potential antibacterial activity. Turk J Biol 29: 203-210.

29. Antara S, Amla B (2012) Evaluation of antimicrobial activity of different solvent extracts of medicinal plant Melia azedarach L. Int $\mathrm{J}$ Curr Pharmaceutl Res 4 : $67-73$

30. Belkacem N, Djaziri R, Lahfa F, El-Haci IA, Boucherit Z (2014) Phytochemical screening and in vitro antioxidant activity of various Punica granatum peel extracts from Algeria: A comparative study. Phytothér 12: 372-379.

31. Cowan MM (1999) Plant products as antimicrobial agents. Clin Microbiol Rev 12: $564-582$

32. Mahindra R, Kateryna K (2013) Fighting multidrug resistance with herbal extracts essential oils and their components (1st edn), Academic press, Elsevier. 